\title{
Identifikasi Keterdapatan Mineral Radioaktif pada Urat-Urat Magnetit di Daerah Ella Ilir, Melawi, Kalimantan Barat
}

\section{Identification of Radioactive Mineral Occurences on Magnetite Veins in Ella Ilir Area, Melawi, West Kalimantan}

\author{
Ngadenin*, Frederikus Dian Indrastomo, Kurnia Setiawan Widana, Widodo \\ Pusat Teknologi Bahan Galian Nuklir-BATAN \\ Jalan Lebak Bulus Raya No.9 Pasar Jumat, Jakarta, Indonesia, 12440 \\ *E-mail: ngadenin@batan.go.id
}

Naskah diterima: 14 Maret 2019, direvisi: 14 April 2019, disetujui: 20 Mei 2019

DOI: $10.17146 /$ eksplorium.2019.40.1.5350

\begin{abstract}
ABSTRAK
Ella Ilir secara administratif terletak di Kabupaten Melawi, Kalimantan Barat. Geologi regional daerah Ella Ilir tersusun atas batuan malihan berumur Trias-Karbon yang diterobos oleh batuan granitik berumur Yura dan Kapur. Keterdapatan mineral radioaktif di daerah tersebut terindikasi dari radioaktivitas urat-urat magnetit pada batuan malihan berumur Trias-Karbon dengan kisaran nilai $1.000 \mathrm{c} / \mathrm{s}$ hingga $15.000 \mathrm{c} / \mathrm{s}$. Tujuan dari penelitian ini adalah menentukan jenis cebakan mineral bijih dan mengidentifikasi keterdapatan mineral radioaktif pada urat-urat bijih magnetit di daerah Ella Ilir. Metode yang digunakan adalah pemetaan geologi, pengukuran radioaktivitas, analisis kadar uranium, dan analisis mineragrafi beberapa sampel urat bijih magnetit. Litologi daerah penelitian tersusun oleh kuarsit biotit, metatuf, metabatulanau, metapelit, granit biotit, dan riolit. Sesar sinistral barat-timur dan sesar dekstral utara-selatan merupakan struktur sesar yang berkembang di daerah ini. Komposisi mineral urat-urat magnetit terdiri dari mineral-mineral bijih besi, sulfida, dan radioaktif. Mineral bijih besi terdiri dari magnetit, hematit, dan gutit. Mineral sulfida terdiri dari pirit, pirhotit, dan molibdenit sedangkan mineral radioaktif terdiri dari uraninit dan gumit. Keterdapatan urat-urat bijih magnetit dikontrol oleh litologi dan struktur geologi. Urat-urat magnetit pada metabatulanau berukuran tebal $(1,5-5 \mathrm{~m})$, mengisi rekahan-rekahan yang terdapat di sekitar zona sesar. Sementara itu, urat-urat magnetit pada metapelit berukuran tipis (milimetriksentimetrik), mengisi rekahan-rekahan yang sejajar dengan bidang sekistositas. Cebakan mineral bijih di daerah penelitian adalah cebakan bijih besi atau cebakan bijih magnetit berbentuk urat karena proses hidrotermal magmatik.
\end{abstract}

Kata kunci: Ella Ilir, cebakan bijih, urat magnetit, mineral radioaktif, sekistositas

\section{ABSTRACT}

Ella Ilir administratively located in Melawi Regency, West Kalimantan. Regional geology of Ella Ilir area is composed of metamorphic rocks in Triassic-Carboniferous age which are intruded by Jurassic and Cretaceous granitic rocks. Radioactive minerals occurences in the area are indicated by magnetite veins radioactivities on Triassic to Carboniferous metamorphic rocks whose values range from 1,000 c/s to $15,000 \mathrm{c} / \mathrm{s}$. Goal of the study is to determine the type of ore mineral deposits and to identify the presence of radioactive mineral in magnetite veins in Ella Ilir area. The methods used are geological mapping, radioactivity measurements, analysis on uranium grades, and mineragraphy analysis of severe magnetite veins samples. Lithologies of the study area are composed by biotite quartzite, metatuff, metasilt, metapellite, biotite granite, and ryolite. The east-west sinistral fault and the north-south dextral fault are the developed fault structures in this area. Mineral composition of magnetite veins are consists of iron ore, sulfide, and radioactive minerals. Iron ore mineral consists of magnetite, hematit, and goetite. Sulfide minerals consist of pyrite, pirhotite, and molybdenite, while radioactive minerals consist of uraninite and gummite. The occurences of magnetite veins are controlled by lithology and geological structures. The magnetite veins in metasilt are thick $(1.5-5 \mathrm{~m})$, filled the fractures in the fault zone. Meanwhile, the magnetite veins in metapellite are thinner (milimetric-centimetric), filled the fractures that are parallel to the schistocity. The ore deposits in the study area are iron ore deposits or magnetite ore deposits formed by magmatic hydrothermal processes.

Keywords: Ella Ilir, ore deposits, magnetite vein, radioactive mineral, schistocity 


\section{PENDAHULUAN}

Ella Ilir merupakan salah satu daerah di Kabupaten Melawi, Kalimantan Barat yang letaknya tidak jauh dari daerah Kalan. Secara geografis daerah penelitian terletak pada posisi koordinat $112^{\circ} 8^{\prime} 10^{\prime \prime}-112^{\circ} 10^{\prime} 00^{\prime \prime}$ Bujur Timur dan $0^{\circ} 34^{\prime} 10^{\prime \prime}-0^{\circ} 35^{\prime} 00^{\prime \prime} \quad$ Lintang Selatan. Daerah penelitian termasuk ke dalam wilayah Desa Nanga Nyuruh, Kecamatan Ella Ilir, Kabupaten Melawi, Provinsi Kalimantan Barat (Gambar 1).

Secara regional, tataan geologi daerah Ella Ilir tersusun atas batuan malihan Pinoh (PzTRp) dan Tonalit Sepauk (Kls) (Gambar 1). Batuan malihan Pinoh terdiri dari sekis kuarsa muskovit, filit, batusabak, batutanduk, beberapa tufa malih dan kuarsit, setempat mengandung andalusit, kordierit dan biotit, jarang silimanit dan garnet [1]. Batuan ini sejak lama diasumsikan berumur Paleozoikum [2] hingga Trias [3]. Namun, pentarikhan U-Pb zirkon pada metapelit malihan Pinoh menunjukkan protolit vulkanogenik berumur Kapur Awal, 130 jtl (juta tahun yang lalu), yang mengalami metamorfosis karena terobosan granitoid Schwaner di Jaman Kapur (80 dan 120 jtl) [4,5].

Granitoid Schwaner tersusun atas tonalit biotit-hornblenda, granodiorit, dan granit. Pentarikhan K-Ar pada granitoid ini menunjukkan kisaran umur 157-77 jtl (YuraKapur) [1,6,7]. Komposisi kimia pada granitoid Schwaner menunjukkan bahwa granit tersebut merupakan granit tipe I berafinitas kalk-alkalin [1,6,8]. Batuan granitoid Schwaner menerobos batuan malihan Pinoh selama periode Yura AkhirKapur Awal membentuk zona metamorfisme kontak [6]. Metamorfisme kontak membentuk mineral-mineral metamorfik, di antaranya hornfels

kordierit-andalusit-silimanit, hornfels andalusit-biotit, dan hornfels andalusit-silimanit [9]. Metatonalit yang berumur Trias Akhir (233 $\pm 3 \mathrm{jtl})$ merupakan batuan magmatik paling tua di Pegunungan Schwaner [10], memiliki kemiripan dengan kompleks Embuoi di Kalimantan bagian barat daya (201-263 jtl) [6] dan granodiorit Jagoi di Sarawak barat (208 jtl) [11]. Batuan malihan Pinoh dan batuan granitoid tersebut menjadi batuan dasar dan berperan sebagai sumber sedimentasi Cekungan Melawi dan cekungan lainnya di Sundaland [10].

Struktur geologi yang berkembang cenderung berasosiasi dengan provinsi geologinya. Sesar dan struktur minor seperti retas dan foliasi dijumpai pada batolit Schwaner sedangkan belahan dan sekis berkembang pada batuan malihan Pinoh. Foliasi yang terbentuk pada tonalit disebabkan karena deformasi tubuh pluton setelah proses magmatisme berakhir. Oleh karena itu, tonalit yang terdeformasi itu disebut juga sebagai metatonalit [1,9] atau tonalit berfoliasi [6] dengan arah umum timur-barat dan timur laut-barat daya [1].

Indikasi keterdapatan mineral radioaktif di Ella Illir ditandai oleh bacaan radioaktivitas yang cukup tinggi dari urat-urat bijih magnetit pada batuan malihan Pinoh, yaitu antara 1.000 hingga $15.000 \mathrm{c} / \mathrm{s}$ [12]. Keterdapatan mineral radioaktif kelompok uranium di Melawi, terutama daerah Kalan umumnya berasosiasi dengan turmalin dan mineral-mineral sulfida [12-16]. Bijih uranium di daerah Kalan secara umum dikelompokkan menjadi dua tipe, yaitu bijih uranium tipe monasit dan bijih uranium tipe turmalin [12-17]. Bijih uranium tipe monasit terdapat di Sektor Rirang dan Tanah Merah $[16,17]$ sedangkan bijih uranium tipe turmalin 
terdapat di Sektor Remaja, Rabau [18], dan sektor lainnya. Kedua tipe bijih dibedakan berdasarkan perbedaan komposisi mineral yang dominan sehingga mempermudah dalam proses pengolahannya.

Teknologi pengolahan bijih uranium tipe turmalin dan pengolahan bijih tipe monasit skala pilot telah dikuasi oleh Pusat Teknologi Bahan Galian Nuklir pada sekitar tahun 1990-2000. Karena letak Ella Ilir yang tidak jauh dari Kalan dan telah dikuasainya teknologi pengolahan uranium tipe turmalin dan tipe monasit maka identifikasi keterdapatan mineral radioaktif di daerah Ella Ilir dianggap cukup menarik dan berpotensi menambah sumber daya atau bahkan cadangan uranium di kawasan Kabupaten Melawi apabila suatu saat bijih uranium Kalan ditambang.

Penelitian ini bertujuan untuk menentukan jenis cebakan bijih dan mengidentifikasi keterdapatan mineral radioaktif pada urat-urat bijih magnetit di batuan malihan Pinoh yang berumur TriasKarbon. Data hasil penelitian selanjutnya akan digunakan sebagai bahan pertimbangan untuk mengembangkan eksplorasi dan pengolahan di masa mendatang terutama di wilayah Kabupaten Melawi, Provinsi Kalimantan Barat.

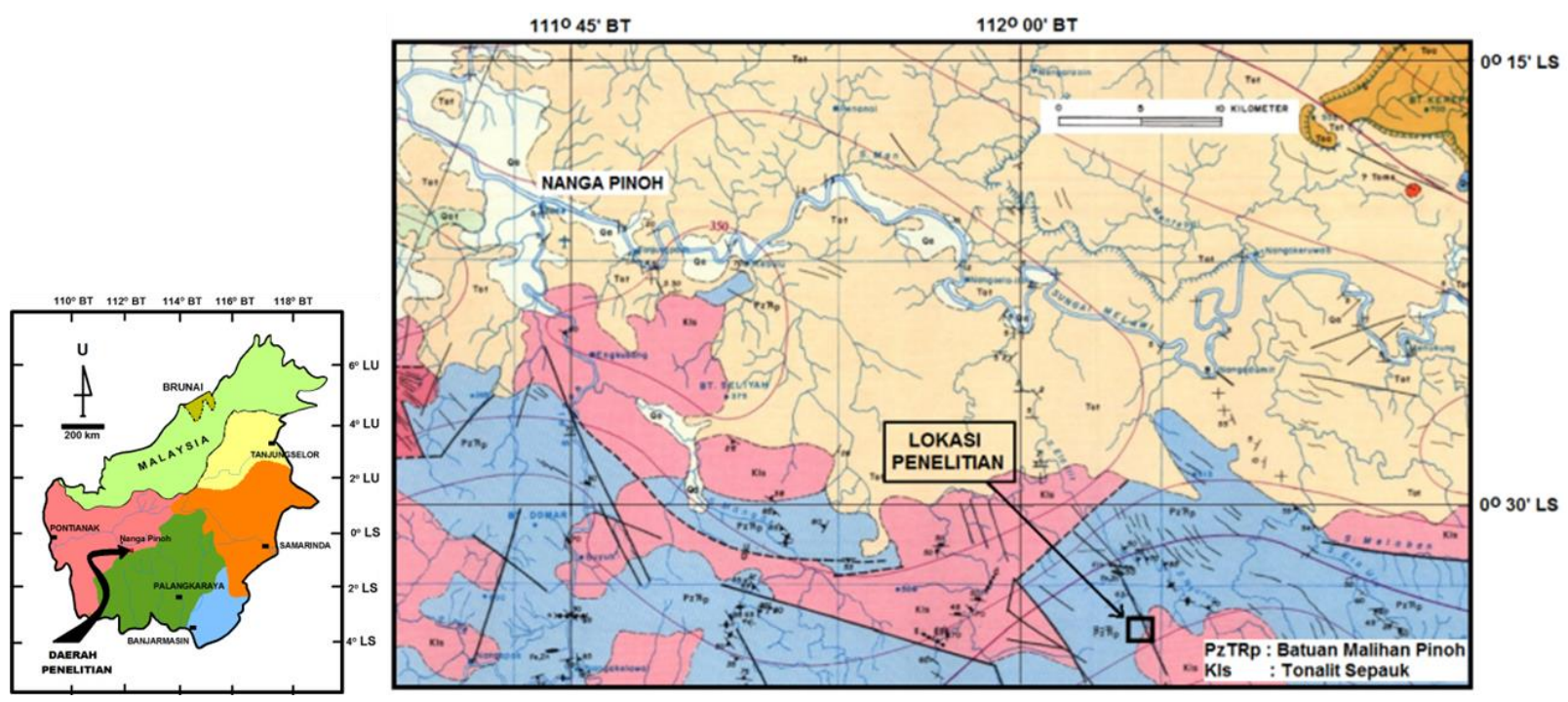

Gambar 1. Peta lokasi dan geologi regional daerah Ella Ilir (dimodifikasi dari [1]).

\section{TATA KERJA}

Peralatan yang digunakan terdiri dari peralatan pemetaan geologi, spektrometer sinar gamma RS 125 untuk mengukur radioaktivitas dan kadar uranium batuan, mikroskop polarisasi sinar tembus untuk analisis petrografi batuan dan mikroskop polarisasi sinar pantul untuk analisis mineragrafi bijih magnetit. Bahan yang digunakan adalah sayatan tipis batuan dan sayatan poles bijih magnetit.
Metode kerja yang dilakukan terdiri dari pemetaan geologi, pengukuran radioaktivitas, pengukuran kadar uranium urat-urat magnetit, pengambilan sampel bijih magnetit, analisis petrografi, dan analisis mineragrafi. Pemetaan geologi dilakukan dengan cara pengamatan singkapan batuan pada lintasan yang telah ditentukan. Sampel batuan diambil pada setiap litologi yang berbeda kemudian dibuat sayatan tipis dan dilakukan analisis petrografi untuk mengetahui komposisi mineralnya. 
Pengukuran radioaktivitas dan kadar uranium urat-urat magnetit dilakukan pada lokasi pengambilan sampel batuan menggunakan alat gamma spektrometer RS 125. Pengambilan sampel bijih magnetit di lapangan dilakukan pada bijih magnetit yang mempunyai radioaktivitas paling sedikit $1.000 \mathrm{c} / \mathrm{s}$. Sampel yang diambil sebanyak lima buah kemudian dibuat sayatan poles dan dianalisis mineragrafi untuk mengetahui komposisi mineralnya.

\section{HASIL}

Morfologi daerah penelitian merupakan perbukitan bergelombang rendah dengan ketinggian antara 64-191 mdpl dan kemiringan lereng 5-40 . Litologi yang menyusun daerah penelitian terdiri atas metapelit, metabatulanau, metatuf, kuarsit biotit, granit biotit, dan riolit (Gambar 2).

Metapelit berwarna coklat muda keunguan, ukuran butir lempung, struktur masif, kadang-kadang memperlihatkan sekistosan, dengan komposisi mineral terdiri atas mineral lempung, biotit, muskovit, kuarsa, kordierit, material organik, serisit, dan andalusit. Metabatulanau berwarna coklat muda, nonfoliasi, blastosemipilitik, berukuran butir lanau, dengan komposisi mineral terdiri dari kuarsa, feldspar, biotit, serisit, dan andalusit. Metatuf berwarna kelabu gelap, berukuran butir lanau-pasir sedang dengan komposisi mineral terdiri atas abu gunungapi, kuarsa, fragmen batuan vulkanik asam dan material organik. Pada batuan metatuf terdapat mineral kordierit dengan ukuran kristal lebih kasar dibanding ukuran butir penyusun batuan. Kordierit berbentuk kristalin, warna abu-abu kecoklatan, terdapat mineralisasi pirit dan magnetit yang menyebar dalam batuan. Kuarsit biotit berwarna kelabu gelap, masif, granoblastik, berbutir halus, dengan komposisi mineral terdiri atas kuarsa, biotit, dan muskovit. Granit biotit berwarna putih berbintik-bintik hitam, holokristalin fanerik, inequigranular, ukuran mineral 2-6 mm, euhedral-subhedral dengan komposisi mineral terdiri atas potasium feldspar (KF), kuarsa, plagioklas, biotit, dan amfibol. Granit ini mengalami proses kaolinisasi cukup intensif. Riolit segar berwarna merah daging agak cerah, hipokristalin afanitik, berukuran butir halus dengan komposisi mineral KF, kuarsa, dan plagioklas.

Struktur geologi yang berkembang adalah perlapisan, foliasi, dan sesar. Perlapisan batuan mempunyai jurus berarah barat laut-tenggara dengan kemiringan 65$83^{\circ}$ ke barat daya. Foliasi mempunyai jurus berarah barat laut-tenggara miring $80-85^{\circ} \mathrm{ke}$ barat daya. Struktur sesar di daerah ini diidentifikasi sebagai sesar mendatar sinistral berarah barat-timur dan sesar mendatar dekstral berarah utara-selatan.

Urat-urat yang mengandung bijih magnetit hanya ditemukan di sebaran dua jenis batuan, yaitu pada kelompok metapelit dan metabatulanau (Tabel 1). Masing-masing kelompok memiliki nilai radiometri cukup tinggi yang berasal dari mineral radioaktif seperti uraninit dan gumit. 


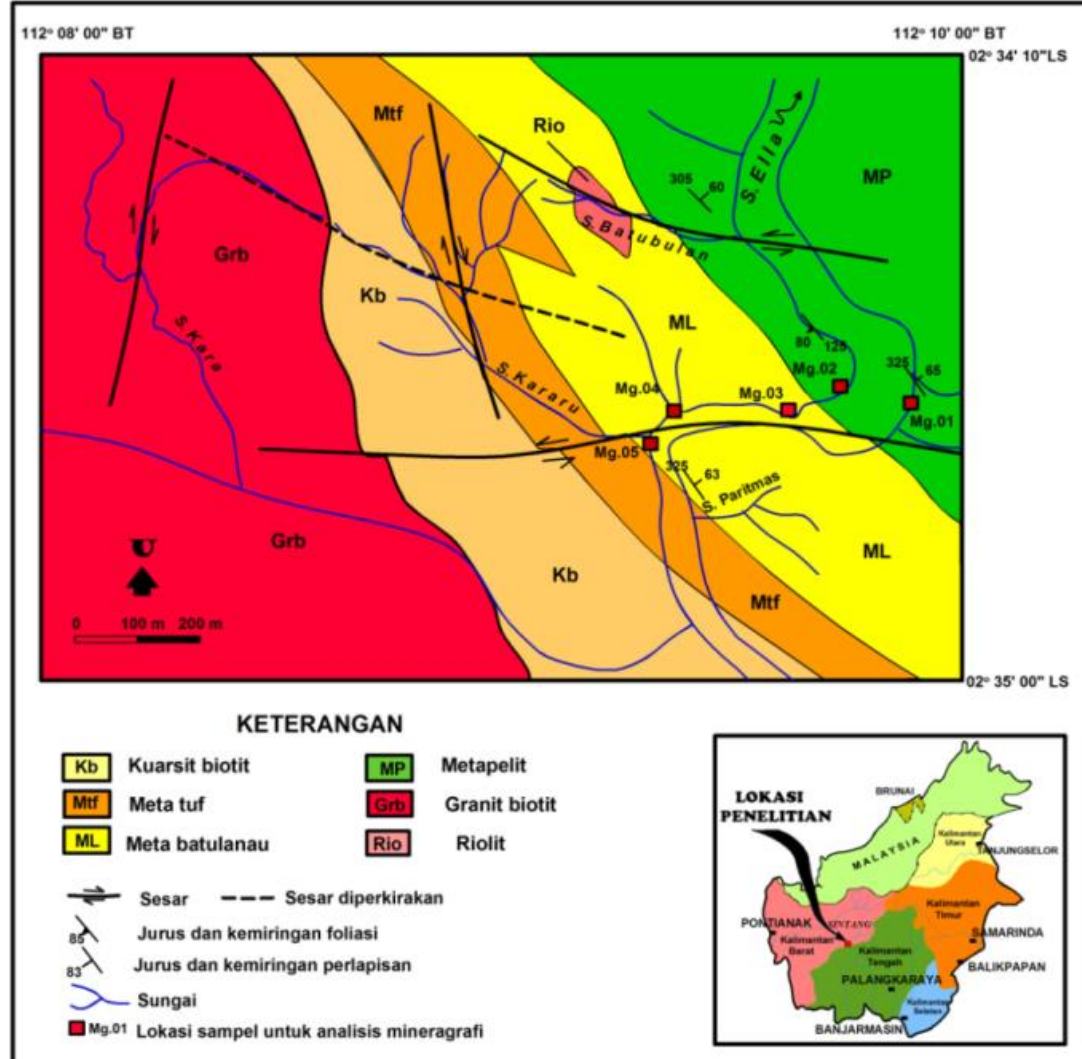

Gambar 2. Peta geologi dan lokasi pengambilan sampel bijih magnetit daerah Ella Ilir, Kabupaten Melawi, Kalimantan Barat.

Tabel 1. Analisis mineral bijih pada urat-urat magnetit.

\begin{tabular}{|c|c|c|c|c|c|}
\hline $\begin{array}{l}\text { Nomor } \\
\text { Sampel }\end{array}$ & Litologi & $\begin{array}{l}\text { Radiometri } \\
(\mathbf{c} / \mathbf{s})\end{array}$ & $\begin{array}{c}\text { Kadar } \\
\text { (ppm } \\
\text { eU) }\end{array}$ & $\begin{array}{c}\text { Kedudukan } \\
\text { Urat }\end{array}$ & Komposisi Mineral \\
\hline MG 01 & $\begin{array}{l}\text { Urat-urat magnetit pada } \\
\text { metapelit, tebal } \\
\text { milimetrik-sentimetrik, } \\
\text { panjang } 2 \text { meter }\end{array}$ & 12.000 & 2.965 & $\mathrm{~N} 130^{\circ} \mathrm{E} / 70^{\circ}$ & $\begin{array}{l}\text { Magnetit } 26 \% \text {, gummit } 4 \% \text {, } \\
\text { molibdenit } 0,01 \% \text {, mineral } \\
\text { transparan } 69,99 \%\end{array}$ \\
\hline MG 02 & $\begin{array}{l}\text { Urat-urat magnetit pada } \\
\text { metapelit, tebal } \\
\text { milimetrik-sentimetrik }\end{array}$ & 4.500 & 660 & $\begin{array}{l}\mathrm{N} 130^{\circ} \mathrm{E} / 75^{\circ} \\
\text { Sekistositas } \\
\mathrm{N} 125^{\circ} \mathrm{E} / 80^{\circ}\end{array}$ & $\begin{array}{l}\text { Magnetit } 10 \% \text {, pirit } 4 \% \text {, } \\
\text { uraninit } 2 \% \text {, molibdenit } 2 \% \text {, } \\
\text { hematit } 0,5 \% \text {, mineral } \\
\text { transparan } 81,5 \%\end{array}$ \\
\hline MG 03 & $\begin{array}{l}\text { Urat-urat magnetit pada } \\
\text { metabatulanau, tebal } 5 \\
\text { meter, panjang } 50 \\
\text { meter }\end{array}$ & 5.000 & 358 & $\begin{array}{l}\mathrm{N} 115^{\circ} \mathrm{E} / 80^{\circ} \\
\text { Perlapisan } \\
\mathrm{N} 325^{\circ} \mathrm{E} / 60^{\circ}\end{array}$ & $\begin{array}{l}\text { Magnetit } 40 \% \text {, uraninit } 2 \% \text {, } \\
\text { hematit } 0,15 \%, \text { mineral } \\
\text { transparan } 57,85 \%\end{array}$ \\
\hline MG 04 & $\begin{array}{l}\text { Urat-urat magnetit pada } \\
\text { metabatulanau, tebal } \\
1,5 \text { meter }\end{array}$ & 7.000 & 1.215 & $\mathrm{~N} 120^{\circ} \mathrm{E} / 90^{\circ}$ & $\begin{array}{l}\text { Magnetit } 75 \% \text {, pirit } 5 \% \text {, } \\
\text { uraninit } 2,5 \% \text {, molibdenit } \\
0,5 \% \text { pirhotit } 0,08 \% \text {, } \\
\text { mineral transparan } 16,92 \%\end{array}$ \\
\hline MG 05 & $\begin{array}{l}\text { Urat-urat magnetit pada } \\
\text { metabatulanau, tebal } 4 \\
\text { meter, panjang } 90 \\
\text { meter }\end{array}$ & 5.000 & 390 & $\begin{array}{l}\text { N } 120^{\circ} / 90^{\circ} \\
\text { N } 100^{\circ} \mathrm{E} / 75^{\circ}\end{array}$ & $\begin{array}{l}\text { Magnetit } 50 \% \text {, pirit } 32 \% \text {, } \\
\text { pirhotit } 6 \% \text {, uraninit } 2,5 \% \text {, } \\
\text { molibdenit } 1 \% \text {, hematit } 1 \% \text {, } \\
\text { gutit } 0,5 \%, \text { mineral } \\
\text { transparan } 7 \%\end{array}$ \\
\hline
\end{tabular}


Urat-urat magnetit pada metapelit dicirikan oleh urat-urat bijih magnetit tipis dengan ketebalan berukuran milimetriksentimetrik dan mengisi rekahan-rekahan yang sejajar dengan bidang sekistositas (Gambar 3). Pengukuran radiometri pada sampel bijih (MG 01 dan 02) menunjukan kisaran nilai 4.500-12.000 c/s dengan kadar ekuivalen uranium 660-2.965 ppm eU. Mineral-mineral radioaktif teridentifikasi dari hasil analisis mineralogi bijih (mineragrafi) adalah uraninit dan gumit. Jumlah uraninit pada kelompok bijih magnetit sebesar $2 \%$, sementara gumit mencapai $4 \%$.

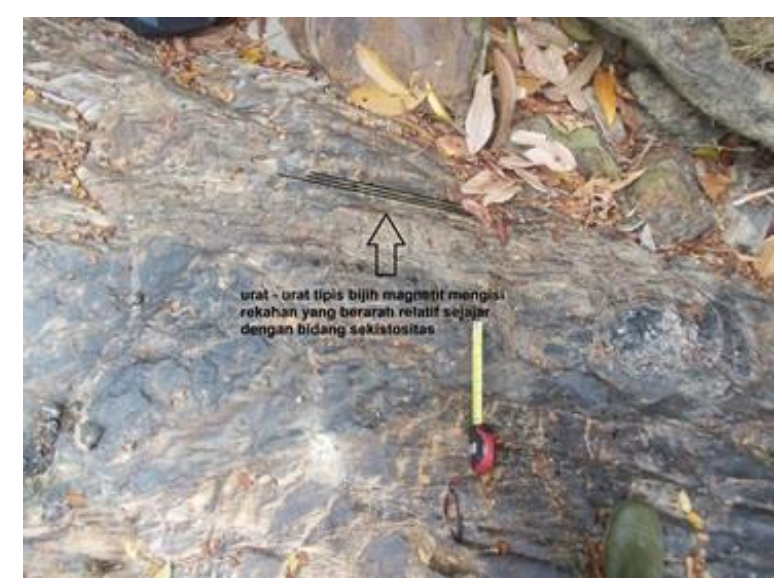

Gambar 3. Bijih magnetit mengisi rekahan sejajar bidang sekistositas di lokasi sampel nomor MG 01 .

Urat-urat bijih magnetit pada metabatulanau dicirikan oleh urat-urat magnetit yang mengisi rekahan-rekahan berarah relatif barat-timur miring subvertikal hingga vertikal dengan ketebalan berukuran 1,5-7 meter dan terdapat pada jalur sesar barat-timur (Gambar 4). Nilai radiometri pada sampel bijih (MG 03-05) berkisar antara 5.000-7.000 c/s dengan kadar ekuivalen uranium 358-1.215 ppm eU. Pengamatan mineralogi bijih (mineragrafi) pada sampel tersebut menunjukkan adanya mineral uraninit sejumlah 2-2,5\% di dalam kelompok mineral magnetit (Gambar 5 dan 6).

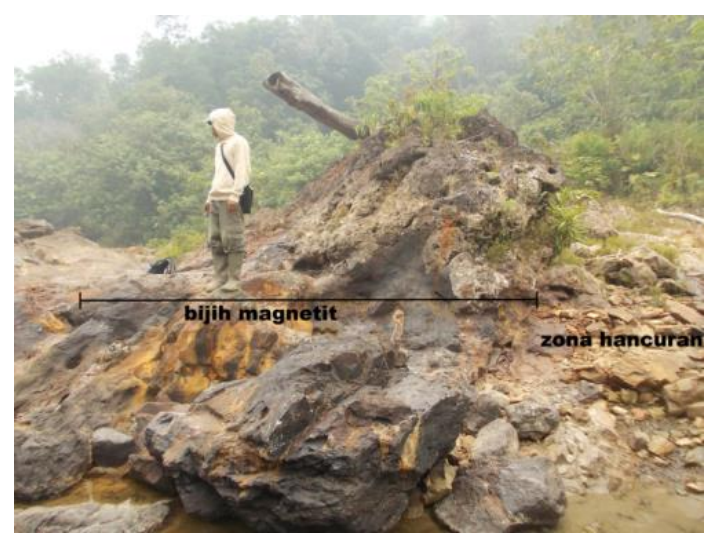

Gambar 4. Bijih magnetit pada metabatulanau di lokasi sampel nomor MG-04.

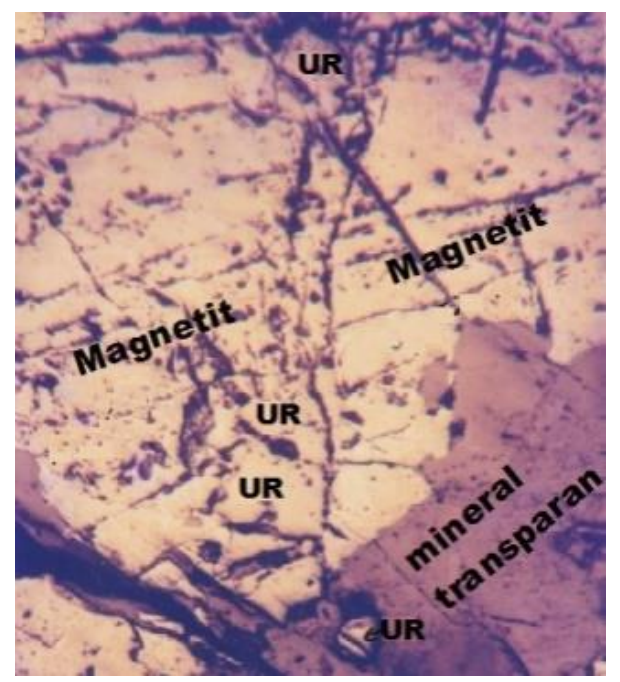

Gambar 5. Hasil analisis mineragrafi menggunakan mikroskop bijih pada sampel MG 03 menunjukkan uraninit berada dalam kelompok magnetit (UR = uraninit).

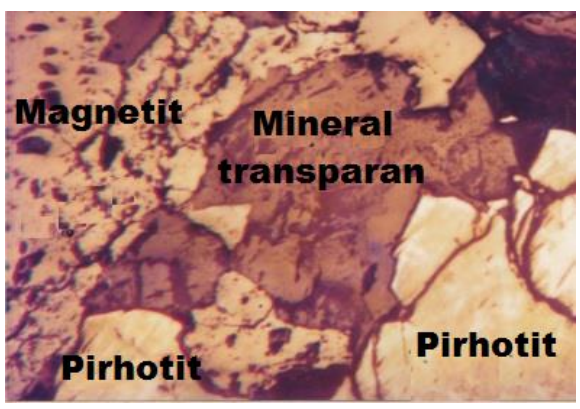

Gambar 6. Mineral sulfida (pirhotit) sebagai mineral asesoris pada bijih magnetit berdasarkan hasil pengamatan mineragrafi sampel MG 05 . 


\section{PEMBAHASAN}

Hasil analisis mineragrafi dari 5 (lima) sampel urat bijih magnetit memperlihatkan bahwa komposisi mineral bijih yang terdapat pada urat-urat tersebut terdiri dari kelompok mineral besi, mineral sulfida, dan mineral radioaktif. Kelompok mineral besi terdiri dari magnetit, hematit, dan gutit. Kelompok mineral sulfida terdiri dari pirit, pirhotit, dan molibdenit. Kelompok mineral radioaktif terdiri dari uraninit dan gumit. Keterdapatan kelompok mineral besi terlihat lebih dominan dibanding kelompok mineral sulfida dan mineral radioaktif sehingga cebakan bijih di daerah penelitian dapat disebut sebagai cebakan bijih besi (iron ore deposits) [19]. Keterdapatan mineral magnetit pada kelompok mineral besi lebih dominan dibanding hematit dan gutit sehingga cebakan bijih besi di Ella Ilir dapat juga disebut sebagai cebakan bijih magnetit (magnetite ore deposits). Di dalam urat-urat magnetit terdapat bijih uranium berupa mineral uraninit sehingga cebakan bijih di Ella Ilir dapat disebut sebagai bijih uranium tipe magnetit. Dengan adanya temuan bijih uranium tipe magnetit di Ella Ilir maka di kawasan Kabupaten Melawi terdapat tiga tipe bijih uranium, yaitu bijih uranium tipe turmalin dan monasit di Kalan, serta bijih uranium tipe magnetit di Ella Ilir.

Cebakan bijih besi (iron ore deposits) dapat terbentuk karena proses magmatisme, hidrotermal, metamorfisme, sedimenter, atau residual. Cebakan bijih besi di daerah penelitian termasuk cebakan bijih tipe hidrotermal yang dicirikan oleh kehadiran mineral magnetit dan molibdenit. Cebakan bijih besi tipe hidrotermal umumnya berbentuk vein atau skarn [20,21]. Urat-urat magnetit yang mengandung uranium di daerah penelitian diperkirakan merupakan cebakan bijih magnetit tipe hidrotermal yang terbentuk oleh pengaruh intrusi granit dan riolit yang terdapat di sekitar daerah penelitian. Cebakan bijih magnetit tipe hidrotermal di daerah penelitian mempunyai kemiripan dengan cebakan bijih magnetit yang terdapat pada Goushti Hydrothermal Magnetite Deposit pada batuan metamorf berumur Mesozoikum di Iran [22].

Kadar uranium sampel bijih magnetit hasil pengukuran di lapangan berkisar antara 358 ppm sampai 2.965 ppm. Kisaran kadar uranium tersebut termasuk kadar sangat rendah $(100 \mathrm{ppm})$ hingga kadar rendah (1.000 ppm) [23]. Kadar uranium pada cebakan bijih besi (iron oxide breccia) polimetalik di tambang Olimpic Dam Australia adalah sekitar 2.000 ppm [24]. Kadar uranium pada cebakan bijih besi tipe urat di tambang Staszic di pegunungan Holy Cross Polandia adalah sekitar 1.200 ppm [25].

Hasil pengamatan singkapan batuan di lapangan memperlihatkan bahwa urat-urat magnetit yang relatif tebal (metrik) terdapat pada rekahan-rekahan di metabatulanau sedangkan urat-urat magnetit yang relatif tipis (milimetrik) dijumpai pada metapelit dengan gejala sekistosan. Terbentuknya fraktur terbuka sebagai perangkap mineralisasi bijih berhubungan dengan sifat plastisitas batuan. Geometri dan arah urat mineralisasi dipengaruhi oleh faktor litologi yang memberikan reaksi fisik yang berbeda terhadap aktivitas tektonik. Pada batuan yang paling halus (metapelit), urat mineralisasi berukuran tipis dan rapat mengisi rekahan yang mempunyai arah relatif sejajar dengan jurus bidang sekistositas sedangkan pada batuan metabatulanau yang lebih masif urat mineralisasi berukuran tebal umumnya berbentuk breksi mineralisasi mengisi rekahan-rekahan di sekitar zona sesar [26]. Pada metabatulanau, mineralisasi uranium yang terbentuk adalah mineral primer berupa 
mineral uraninit sedangkan pada metapelit berupa uraninit dan mineral sekunder berupa gummit. Kontrol mineralisasi uranium di daerah penelitian mirip seperti kontrol mineralisasi di sektor Remaja, Kalan, Kalimantan Barat.

Secara regional di Kalimantan terjadi tiga kali magmatisme, yaitu magmatisme granitoid pada jaman Trias, magmatisme granitoid jaman Yura, dan magmatisme granitoid jaman Kapur. Magmatisme jaman Trias ditandai oleh batuan beku yang berfoliasi dari Komplek Emboui yang tersingkap di bagian barat dari Serawak Barat dan granodiorit Jagoi di Serawak Barat, serta batuan beku di bagian barat laut Kalimantan Barat di sekitar Gunung Biwa dan Gunung Tunggal. Magmatisme jaman Yura ditandai oleh singkapan batuan granitik di daerah Ketapang yang dapat disebandingkan dengan granit Sukadana. Magmatisme jaman Kapur ditandai oleh singkapan batuan magmatis pada beberapa daerah di Kabupaten Ketapang, Kalimantan Barat dan dapat disebandingkan dengan Tonalit Sepauk [27]. Mineralisasi uranium di daerah penelitian diperkirakan berhubungan dengan proses magmatisme granitoid jaman Yura seperti mineralisasi uranium di daerah Kalan, Kabupaten Melawi.

\section{KESIMPULAN}

Tipe cebakan bijih di daerah penelitian adalah cebakan bijih besi yang terdiri dari magnetit, hematit, dan gutit berbentuk uraturat oleh proses hidrotermal. Mineral aksesorisnya terdiri dari mineral sulfida (pirit, pirhotit, dan molibdenit) dan mineral radioaktif (uraninit dan gumit). Oleh karena mineral bijih yang dominan pada cebakan bijih besi adalah magnetit dan di dalamnya terkandung kelompok mineral uranium, yaitu uraninit dan gumit, maka cebakan uranium di Ella Ilir dapat disebut sebagai cebakan bijih uranium tipe magnetit. Keterdapatan urat-urat bijih magnetit dikontrol oleh litologi dan struktur geologi. Urat-urat magnetit pada metabatulanau berukuran cukup tebal (1,5-5 meter) terdapat di sekitar zona sesar sinistral barat-timur sedangkan urat-urat magnetit pada metapelit berukuran tipis (milimetriksentimetrik) mengisi rekahan-rekahan yang sejajar dengan bidang sekistositas.

\section{SARAN}

Teknologi pengolahan bijih uranium tipe turmalin dan bijih uranium tipe monasit dari daerah Kalan pada skala pilot telah dikuasai oleh Pusat Teknologi Bahan Galian NuklirBadan Tenaga Nuklir Nasional. Dengan adanya temuan baru bijih uranium tipe magnetit di daerah Ella Ilir maka penulis menyarankan agar dilakukan penelitian pengolahan bijih uranium tipe magnetit skala laboratorium.

\section{UCAPAN TERIMA KASIH}

Penulis mengucapkan terima kasih kepada Bapak Yarianto Sugeng Budi Susilo sebagai Kepala Pusat Teknologi Bahan Galian Nuklir yang telah memberi kesempatan penulis untuk melakukan penelitian. Terima kasih juga penulis sampaikan kepada Bapak Heri Syaeful sebagai Kepala Bidang Eksplorasi yang telah mendukung penelitian ini dan teman-teman di laboratorium mineralogi yang telah membantu melakukan preparasi sampel sehingga penelitian ini dapat berjalan lancar.

\section{DAFTAR PUSTAKA}

[1] Amiruddin and D. S. Trail, Peta Geologi Lembar Nanga Pinoh Kalimantan Skala 1: 250.000. Bandung: Pusat Penelitian dan Pengembangan Geologi, 1993. 
[2] R. B. Tate, "Cross-border Correlation of Geological Formations in Sarawak and Kalimantan," Bulletin of the Geological Society of Malaysia, vol. 28, pp. 63-95, 1991.

[3] P. E. Pieters and P. Sanyoto, Peta Geologi Lembar Pontianak/Nangataman, Kalimantan Skala 1:250.000. Bandung: Pusat Penelitian dan Pengembangan Geologi, 1993.

[4] L. Davies, R. Hall, and R. Amstrong, "Cretaceous Crust in SW Borneo: Petrological, Geochemical and Geochronological Constraints from the Schwaner Mountains," in Proceedings Indonesian Petroleum Association, 38th Annual Convention and Exhibition, pp. IPA14-G-025, May, 2014.

[5] L. B. Davies, SW Borneo Basement: Age, origin and character of igneous and metamorphic rocks from the Schwaner Mountains. London: Royal Holloway University of London, 2013.

[6] P. R. Williams, C. R. Johnston, R. A. Almond, and W. H. Simamora, "Late Cretaceous to Early Tertiary Structural Elements of West Kalimantan," Tectonophysics, vol. 148, no. 3-4, pp. 279-297, 1988.

[7] N. S. Haile, M. W. McElhinny, and I. McDougall, "Palaeomagnetic Data and Radiometric Ages from the Cretaceous of West Kalimantan (Borneo), and Their Significance in Interpreting Regional Structure," Journal of the Geological Society, vol. 133, no. 2, pp. 133-144, 1977.

[8] Amiruddin, "Cretaceous Orogenic Granite Belts, Kalimantan, Indonesia," Jurnal Geologi dan Sumber Daya Mineral, vol. 19, no. 3, pp. 167176, 2009.

[9] N. I. Setiawan, Y. Osanai, N. Nakano, T. Adachi, K. Yonemura, A. Yoshimoto, J. Wahyudiono, and K. Mamma, "An Overview of Metamorphic Geology from Central Indonesia: Importance of South Sulawesi, Central Java and South-West Kalimantan Metamorphic Terranes," Bulletin of the Graduate School of Social and Cultural Studies, Kyushu University, vol. 19, pp. 39-55, 2013.

[10] N. I. Setiawan, Y. Osanai, N. Nakano, T. Adachi, L. D. Setiadji, and J. Wahyudiono, "Late Triassic Metatonalite from the Schwaner Mountains in West Kalimantan and its contribution to Sedimentary Provenance in the Sundaland," Berita Sedimentologi, vol. 12, no. 28, pp. 4-12, 2013.

[11] H. T. Breitfeld, R. Hall, T. Galin, M. A. Forster, and M. K. BouDagher-Fadel, "A Triassic to Cretaceous Sundaland-Pacific Subduction Margin in West Sarawak, Borneo," Tectonophysics, vol. 694, pp. 35-56, 2017.

[12] BATAN CEA, Prospect To Development Uranium Deposits In Kalimantan, Volume I (General Reconaissance), Jakarta, 1976.
[13] Ngadenin, A. Sumaryanto, H. Syaeful, and I. G. Sukadana, "Geologi dan Mineralisasi Uranium Daerah Kalan, Kabupaten Melawi, Kalimantan Barat," in Prosiding Seminar Nasional Kebumian XII, pp. 108-114, Sept. 14, 2017.

[14] Ngadenin, D. Soetarno, S. Tjokrokardono, R. Witjahyati, L. Subiyantoro, M. Widodo, B. Soetopo, Y. Wusana, Rusmadi, Handoko, Sujiman, and Paimin, Sintesis Geologi dan Mineralisasi Uranium Cekungan Kalan, Kalimantan Barat, in: Kapita Selekta Sintesis Geologi dan Mineralisasi Uranium Kalan dan Sekitarnya Serta Perspektif Perkembangan Permintaan, Pasokan dan Harga Uranium Dunia, Suprapto,dkk (Ed.), Pusat Pengembangan Bahan Galian Nuklir-BATAN, Jakarta, 2005.

[15] S. Tjokrokardono, B. Soetopo, L. Subiantoro, and K. S. Widana, Geologi dan Mineralisasi Uranium Kalan, Kalimantan Barat, in: Kumpulan Laporan Hasil Penelitian Tahun 2005, BATAN, Jakarta, 2005, pp. 27-52.

[16] K. Busch, S. Tjokrokardono, and Djawadi, "Investigation of The uranium Mineralization in Rirang Valey, West Kalimantan, Indonesia," Bonn, 1986.

[17] M. Widodo, Suharji, Rusmadi, Subagyo, R. Iswanto, and A. Sutriyono, Sintesis Geologi dan Mineralisasi U Sektor Rirang, Kalan, Kalimantan Barat, in: Kapita Selekta Sintesis Geologi dan Mineralisasi Uranium Kalan dan Sekitarnya Serta Perspektif Perkembangan Permintaan, Pasokan dan Harga Uranium Dunia, Suprapto,dkk (Ed.), Pusat Pengembangan Bahan Galian NuklirBATAN, Jakarta, 2005, pp. 91-107.

[18] B. Soetopo, R. Witjahyati, and Y. Wusana, "Sintesa Geologi dan Pemineralan Uranium Sektor Rabau Hulu, Kalan, Kalimantan Barat," in Prosiding Seminar Geologi Nuklir dan Sumberdaya Tambang Tahun 2004, pp. 85-99, Sept. 22, 2004.

[19] H. M. Li, L. X. Li, X. Q. Yang, and Y. B. Cheng, "Types and Geological Characteristics of Iron Deposits in China," Journal of Asian Earth Sciences, vol. 103, pp. 2-22, 2015.

[20] P. Nadoll, J. L. Mauk, R. Leveille, L. Fisher, and R. Hough, "Magnetite - An Indicator Mineral for Hydrothermal Ore Deposits," in Workshop on Processes that control the trace elements of $\mathrm{Fe}$ oxides in ore deposits, June 30, Montreal, 2012.

[21] P. Nadoll, T. Angerer, J. L. Mauk, D. French, and J. Walshe, "The Chemistry of Hydrothermal Magnetite: A Review," Ore Geology Reviews, vol. 61, pp. 1-32, Sept., 2014.

[22] M. A. Rajabzadeh and S. Rasti, "Investigation on Mineralogy, Geochemistry and Fluid Inclusions of the Goushti Hydrothermal Magnetite Deposit, Fars Province, SW Iran: A Comparison with IOCGs," Ore Geology Reviews, vol. 82, pp. 93107, April, 2017. 
[23] National Research Council, Uranium Mining in Virginia: Scientific, Technical, Environmental, Human Health and Safety and Regulatory Aspect of Uranium Mining and Processing in Virginia. Washington D.C.: The National Academies Press, 2012.

[24] A. Chaki, R. K. Putrohit, and R. Mamallan, "Low Grade Uranium Deposits of India - A Bane or Boon," Energy Procedia, vol. 7, no. 153-157, 2011.

[25] K. Kiegiel, A. Miskiewicz, D. Gajda, S. Sommer, S. Wolkowicz, and G. Zakrzewska-Koltuniewicz, Uranium in Poland: Resources and Recovery from Low-Grade Ores, in: Uranium: Safety, Resources, Separation and Thermodynamic
Calculation, IntechOpen, London, 2018.

[26] S. Papeschi, G. Musumeci, and F. Mazzarini, "Heterogeneous Brittle-Ductile Deformation at Shallow Crustal Levels Under High Thermal Conditions: The Case of a Synkinematic Contact Aureole in the Inner Northern Apennines, Southeastern Elba Island, Italy," Tectonophysics, vol. 717, pp. 547-567, 2017.

[27] J. Hennig, H. T. Breitfeld, R. Hall, and A. M. S. Nugraha, "The Mesozoic Tectono-Magmatic Evolution at the Paleo-Pacific Subduction Zone in West Borneo," Gondwana Research, vol. 48, pp. 292-310, 2017. 